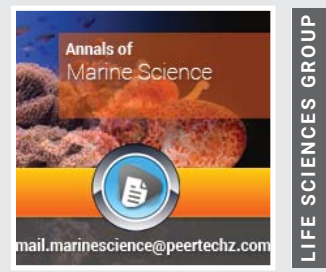

\title{
Case Report: First occurrence of Lymphocystis disease virus 3 (LCDV-Sa) in Wild Marine
}

\section{Fish in Tunisia}

\author{
Nadia Cherif*, Fatma Amdouni, Kaouther Maatoug and \\ Sami Zaafran
}

National Institute of Sea Sciences and Technologies, 28 Rue de 2 Mars, 2025, Tunisia

Received: 18 March, 2020

Accepted: 25 May, 2020

Published: 26 May, 2020

*Corresponding author: Nadia Cherif, National Institute of Sea Sciences and Technologies, 28 Rue de 2 Mars. 2025. Tunisia, Tel/Fax: 0021671735848 ;

E-mail:n.cherif@hotmail.com; nadia.cherif@instm.rnrt.tn

Keywords: LCDV; Healthy carriers; Management; Aquaculture; Tunisia

https://www.peertechz.com

Check for updates

\section{Abstract}

The results of the present study describe the molecular identification of Lymphocystis Disease Viral partial genome (LCDV-Sa) and histopathology in skin nodules and internal organs of Tunisian gilthead sea bream (Sparus aurata). The report supports as well as the existence of multiple reservoirs of LCDV within wild fish species caught near the cage facility; delivering a list of possible vector species susceptible to transmit the disease to farmed sea bream. Histology sections revealed irregular nucleus with basophilic cytoplasmic inclusions. In addition, to the best of our knowledge, molecular results added new viral reservoirs to the list of susceptible fish species described worlwide, including Sardinella aurita, Sardina pilchardus, Trachurus trachurus, Sarpa salpa, Diplodus vulgaris, Diplodus puntazzo, Liza aurata, Sparus aurata, Diplodus anularis, and Spicara maena. The virus detection was not correlated with neither the fish species nor the sampling temperature which varied between $15^{\circ} \mathrm{C}$ and $25^{\circ} \mathrm{C}$. Partial sequence analysis of the MCP gene indicated that the newly identified LCDV strains were clustered within genotype VII and shared $96-100 \%$ of sequence identity with previously identified Tunisian LCDV sequences from farmed sea bream.
\end{abstract}

\section{Introduction}

Lymphocystis Disease (LD) is a rarely fatal, chronic and slowly developing disease, that affects over 150 different marine and fresh water fish species [1-8]. These include species that are of a particular importance for fish farming, such as Sparus aurata (gilthead sea bream). The typical sign of lymphocystis disease is the presence of small pearl-like nodules on the skin and fins of affected fish, that may occur singly or more generally grouped in raspberry-like clusters of tumorous appearance [9]. The external clinical signs of affected fish make them unmarketable [10] and more susceptible to other bacterial, viral or parasitic infections; increasing mortality rates and important economic loss. The etiological agent of LCD is the Lymphocystis Disease Virus (LCDV), a member of the genus Lymphocystivirus, family Iridoviridae. The Major Capsid Protein (MCP) gene represents an important molecular marker for the LCDV genotyping [11,12]. Data obtained on the basis of MCP sequences currently support the existence of nine genotypes in the genus Lymphocystis virus [13]. The genotype
VII represents isolates obtained from sea bream and senegalese sole Solea senegalensis [14].

Tunisia imports more than $70 \%$ of the juvenile fish needed for marine cage farming. Currently, the aquatic bio-security and fish health management protocols used are minimal. Existing measures for disease prevention rely on the use of general prophylactic practices, such as good husbandry practices, reduced stocking density and enforcing the virological control of specimen to be introduced in the farming sites in order to detect carrier fish. This manuscript describes the detection of lymphocystis disease virus (LCDV) in gilthead sea bream, from both asymptomatic and diseased fish, collected at several Tunisian farms. It also describes the detection of LCDV in a number of asymptomatic specimens belonging to different wild fish species collected around farming facilities.

\section{Materials and methods}

During the routine auto-control for viral diseases by Tunisian fish farmers during 2015-2016, gilthead sea bream 
fish were randomly collected from four production facilities located at the Sahel region (Central-East coast), approximately 8 to10 kilometers far from each other. A total of 37 pooled samples were obtained from clinically ill and healthy Sparus aurata specimens, belonging to different growth stages were analyzed by molecular tools in order to detect LCDV. Samples included newly imported juveniles from different South European hatcheries. In addition, 96 wild fish specimens were caught around or inside S. auarta cages and processed in order to screen new viral reservoirs. Wild specimen species were identified based on Food and Agriculture Organization fish identification sheets [15].

Internal organs (liver, kidneys, and spleen), nervous tissues (eyes and brain), portions of skin and caudal fins, obtained individually from wild fish samples or pooled (5 specimen/ pool) from farmed sea bream samples, suspended $(1 / 10, \mathrm{w} / \mathrm{v})$ in Leibovitz medium (L-15) supplemented with $2 \% \mathrm{FBS}, 2 \%$ L-glutamine and $1 \%$ antibiotic solution (100 IU penicillin and100 mg streptomycin $/ \mathrm{mL}$ ), and subsequently homogenized (Table 1). For histological studies, the fins and skin nodules of infected sea bream fish were immediately preserved in $10 \%$ neutral-buffered formalin solution, sectioned transversally and longitudinally, exchanged to ethanol, dehydrated and embedded in paraffin blocks. Tissues were sectioned to $5 \mu \mathrm{m}$ and stained with hematoxylin and eosin. The section samples were observed by light microscopy.

Total DNA was extracted from fish tissue homogenates using the QIAamp DNA Blood and Tissue Kit (Qiagen) according to the manufacturer's instructions. DNA quantity and purity (260/280 ratio) were estimated in a RNA/DNA Calculator (Nanodrop, thermo scientific). A DNA plasmid including a 609 bp region from the MCP gene corresponding with nucleotide positions 99 to 707 of the LCDV SA9 MCP gene (GenBank accession no. GU320728) was generously supplied by Dr. Dolores Castro (University of Malaga, Spain) and used in this study as a positive control. End point PCR assays were performed using the GoTaq Green Master Mix (Promega Madison, USA) in a total volume of $25 \mu \mathrm{l}$. The reaction contained $0.6 \mu \mathrm{M}$ of each primer [10] and $50 \mathrm{ng}$ of extracted DNA in addition to $10 \mathrm{mM}$ of dNTP, $50 \mathrm{mM}$ of $\mathrm{Mgcl} 2$, and 2,5 $\mathrm{\mu l}$ of $10 \mathrm{X}$ enzyme buffer. Cycling parameters were: $1 \mathrm{~min}$ denaturation $\left(95^{\circ} \mathrm{C}\right), 30 \mathrm{~min}$ annealing $\left(50^{\circ} \mathrm{C}\right)$ and $1 \mathrm{~min}$ extension $\left(72^{\circ} \mathrm{C}\right)$ for 35 cycles. The reaction was started by a denaturation step ( 2 min at $94{ }^{\circ} \mathrm{C}$ ) and ended by a $5 \mathrm{~min}$ extension step at $72{ }^{\circ} \mathrm{C}$. In every set of experiments, DNA from non-infected $\mathrm{BF}-2$ cells was included as negative control. In a second time, a nested PCR reaction using an internal primer set LCDVm-F/LCDVm-R [16] was performed in order to improve the sensitivity of the diagnosis of the LCDV genome from asymptomatic fish specimens following the same amplification parameters as described in the first PCR. DNA products were analyzed on 1\% agarose gels containing SYBR safe (Invitrogen), purified and sent to be sequenced. BLASTN analysis (http://blast.ncbi.nlm.nih.gov/ Blast.cgi) was conducted with representative virus sequences exhibiting significant sequence. MCP gene nucleotide sequences of 39LCDV isolates available in GenBank were includedin the analyses.Pair wise comparison was performed using the
Table 1: Summary of fish species, total number and percentages of positive samples during the LCDV screening survey including results from conventional PCR followed by a nested PCR.

\begin{tabular}{|c|c|c|c|c|c|}
\hline Zone & $\operatorname{Temp}^{\circ} \mathrm{C}$ & Fish Species & Length & $\begin{array}{l}\text { Number } \\
\text { tested }\end{array}$ & $\begin{array}{c}\text { Nested PCR } \\
\text { result }\end{array}$ \\
\hline \multirow{5}{*}{ A } & \multirow{5}{*}{$15^{\circ} \mathrm{C}$} & Sardinella aurita & $16 \mathrm{~cm}$ & 1 & + \\
\hline & & Sardinapilchardus & $13,5 \mathrm{~cm}$ & 4 & + \\
\hline & & Sardinapilchardus & $13,8 \mathrm{~cm}$ & 4 & + \\
\hline & & Sardinapilchardus & $14,6 \mathrm{~cm}$ & 5 & - \\
\hline & & Sardinapilchardus & $14,8 \mathrm{~cm}$ & 5 & - \\
\hline \multicolumn{4}{|c|}{ Total number (prevalence of LCDV \%) } & \multicolumn{2}{|c|}{$9 / 19(47 \%)$} \\
\hline \multirow{16}{*}{ B } & \multirow{16}{*}{$15-20^{\circ} \mathrm{C}$} & Trachurustrachurus & $18,4 \mathrm{~cm}$ & 3 & + \\
\hline & & Sardinella aurita & $19,1 \mathrm{~cm}$ & 3 & - \\
\hline & & Sarpasalpa & $24,3 \mathrm{~cm}$ & 1 & - \\
\hline & & Boopsboops & $23,5 \mathrm{~cm}$ & 3 & - \\
\hline & & Diplodus vulgaris & $13 \mathrm{~cm}$ & 1 & - \\
\hline & & Sarpasalpa & $22,5 \mathrm{~cm}$ & 1 & + \\
\hline & & Boopsboops & $22,8 \mathrm{~cm}$ & 3 & - \\
\hline & & Trachurstrachurus & $17,6 \mathrm{~cm}$ & 4 & - \\
\hline & & Sparus aurata & $18,4 \mathrm{~cm}$ & 4 & - \\
\hline & & Trachurustrachurus & $20,8 \mathrm{~cm}$ & 3 & - \\
\hline & & Boobs boops & $17,3 \mathrm{~cm}$ & 1 & - \\
\hline & & Trachurstrachurus & $19,6 \mathrm{~cm}$ & 3 & - \\
\hline & & Sardinapilchardus & $20,8 \mathrm{~cm}$ & 4 & - \\
\hline & & Trachurstrachurus & $20,7 \mathrm{~cm}$ & 3 & - \\
\hline & & Diplodus vulgaris & $13,7 \mathrm{~cm}$ & 1 & + \\
\hline & & Boobs boops & $16,7 \mathrm{~cm}$ & 1 & - \\
\hline \multicolumn{4}{|c|}{ Total number (prevalence of LCDV \%) } & \multicolumn{2}{|c|}{$5 / 39(12.8 \%)$} \\
\hline \multirow{6}{*}{ C } & \multirow{6}{*}{$20-22^{\circ} \mathrm{C}$} & Diplodussargus & $25,5 \mathrm{~cm}$ & 1 & - \\
\hline & & Diploduspuntazzo & $13 \mathrm{~cm}$ & 1 & + \\
\hline & & Diplodus vulgaris & $14 \mathrm{~cm}$ & 2 & - \\
\hline & & Liza aurata & $25,1 \mathrm{~cm}$ & 1 & + \\
\hline & & Liza aurata & $21 \mathrm{~cm}$ & 2 & - \\
\hline & & Sparus aurata & $18,3 \mathrm{~cm}$ & 2 & + \\
\hline \multicolumn{4}{|c|}{ Total number (prevalence of LCDV \%) } & \multicolumn{2}{|c|}{$4 / 9(44.4 \%)$} \\
\hline \multirow{6}{*}{$\mathrm{D}$} & \multirow{6}{*}{$18-25^{\circ} \mathrm{C}$} & Boopsboops & 10.29 & 4 & - \\
\hline & & Diplodusanularis & $13,6 \mathrm{~cm}$ & 1 & + \\
\hline & & Sparus aurata & $23,6 \mathrm{~cm}$ & 3 & - \\
\hline & & $\begin{array}{c}\text { Spondyliosoma } \\
\text { cantharus }\end{array}$ & $12 \mathrm{~cm}$ & 4 & - \\
\hline & & Boopsboops & $14 \mathrm{~cm}$ & 9 & - \\
\hline & & Spicaramaena & $15 \mathrm{~cm}$ & 4 & + \\
\hline \multicolumn{4}{|c|}{ Total number (prevalence of LCDV \%) } & \multicolumn{2}{|c|}{$5 / 29(17.2 \%)$} \\
\hline
\end{tabular}

blast2seqprogram (http://www.ncbi.nlm.nih.gov/blast/bl2seq/ wblast2.cgi).Nucleotide partial sequences of the MCP gene were aligned via the MEGA6 [17] software using the Muscle method, and final adjustments were performed manually. The phylogenetic tree was constructed using the MEGA6 with UPGMA method and the final phylogenetic tree was drawn with the Coral DRAWX6 program. Because the sequences from GenBank were heterogeneous in length, the longer sequences were cut and adapted to the shortest. The reliability of the tree was inferred using the bootstrap method with 1000 replicates [18]. The partial nucleotide sequences of the LCDV strains screened in the present study were not deposited in Gen Bank because they are less than $200 \mathrm{pb}$.

\section{Results}

Histological results revealed that the lesions sampled from the skin and fins of infected S. aurata exhibited several characteristics that are known to be associated with LCD: ie 
infected cells did not invade underlying muscular tissue, cells were severely hypertrophied, hyaline capsules clearly surround infected cells, and basophilic intra cytoplasmic inclusions are visible (Figures $1 \mathrm{~A}-\mathrm{C}$ ). Histological sections stained with hematoxylin and eosin revealed irregular nucleus with margination of chromatin and basophilic intra-cytoplasmic inclusions (Figure 1D).

The identification of the wild fish specimen caught for the survey revealed 13 fish species belonging to five different families including the Sparidae, the Clupeidae, the Mugilidae, the Centracanthidae and the Carangidae, with no clinical signs.

The number of positive LCDV samples found within wild specimens at the studied locations is detailed in Table 2. Nested PCR results show that the virus was present at all the four geographical areas with a prevalence that varied between 34 to $44,7 \%$. Positive wild fish species were as follows: Sardinella aurita, Sardina pilchardus, Trachurus trachurus, Sarpa salpa, Diplodus vulgaris, Diplodus puntazzo, Liza aurata, Sparus aurata, Diplodus anularis, and Spicara maena. The virus detection was not correlated with neither the fish species nor the sampling temperature which varied between $15^{\circ} \mathrm{C}$ and $25^{\circ} \mathrm{C}$.

The comparison of three partial MCP gene sequences, obtained from farmed gilthead sea bream Sparus auarata (SA1Tun16, SA2-Tun16 and SA3-Tun16), to the available reference sequences retrieved from Gene Bank (Table 2) showed nucleotide identities of $96-100 \%$ with the gilthead LCDV strains classified as genotype VII. Lower homology was obtained with sequences of other genotypes. Four sequences were obtained from wild fish specimens, as follows: Sarpa salpa (SS1-Tun16), Sparus aurata (Sarau1-Tun16), Diplodus vulgaris (DV1-Tun16) and Diplodus annularis (DA1-Tun16). The comparison of their partial MCP sequences exhibited $96-100 \%$ of sequence identity with LCDV genotype VII representatives as well. The phylogenetic tree based on MCP gene partial nucleotide sequences confirmed
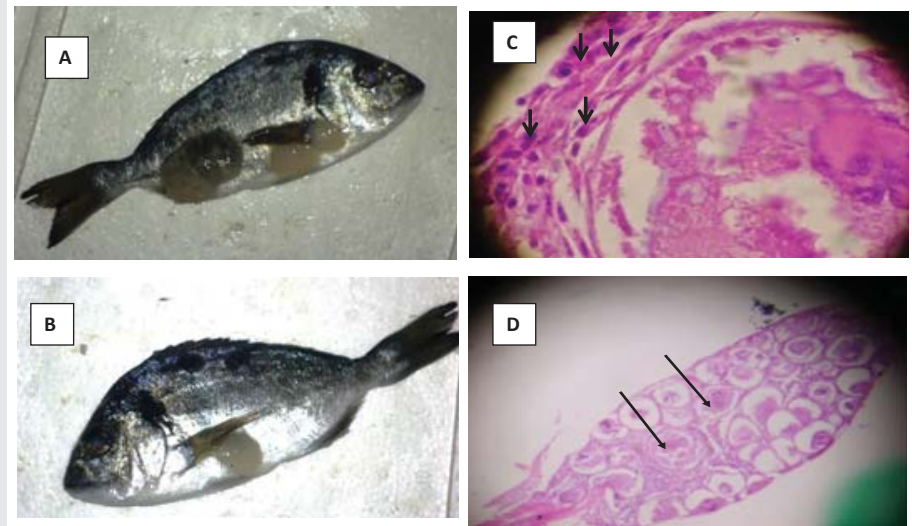

Figure 1: (A) and (B) photos showing sea bream fish showing a massive LDV infection at a late stage characterized by numerous cysts sprayed a1l over the body. Lymphocystisdisease presented as extensive nodules on the pectoral, dorsal and caudal fins, as well as on the operculum, around the eyes and on the trunk(bar $5 \mathrm{~cm}$ ). (C)Typicallymphocystis disease nodules coalesced intolarge masses of hypertrophied cells and had a granular appearance. Arrows showing cross section of enlarged LCD infected tumors cells (bar $50 \mu \mathrm{m}$ ), (D)lymphocystis-affected dermis showing hypertrophic (lymphocystis)cells which occupied a prominent portion of the dermis Hematoxylin-eosin section from a skin mass observed in freshly caught specimen (bar 200 $\mu \mathrm{m})$. the classification of the Tunisian LCDV within the genotype VII, regardless the fish host and the geographic origin (Figure 2). The newly listed sequences were not deposited to a public access database as they were less than $200 \mathrm{nt}$.

\section{Discussion}

LCDV outbreaks are frequently observed in the Mediterranean gilthead sea bream aquaculture [19] even though, it is usually described as a self-limiting disease, there have been several reports on mortalities ranging up to $45 \%$ in juvenile fish, which were related to secondary bacterial infections. Alternatively mortality may be linked to lymphocystis lesions which may severely impair fish respiration and/or feeding [20,21].

Very little proactive viral surveillance in North Africa there has been conducted, subsequently, few epidemiological data related to this virus in this region of the Mediteranean sea is available.

African Lymphocystis viral isolates have only been identified in Cichlids; including species of Tilapia in Lakes Victoria (Nyanza) (Oreochromis variabilis and Haplochromis spp.), in Lake George (H. elegans) and in Lake Kitangiri (Tilapia amphimelas and 0. esculentus) in East Africa [22]. In Tunisia, LCDV has only been identified in farmed sea bream (S. aurata) specie [23].

The results of the present study support the existence of multiple reservoirs of LCDV at the farm facilities. To the best of our knowledge, this report describes the first identification of lymphocystis disease virus from wild Tunisian fish delivering a list of possible vector species susceptible to transmit the disease to farmed sea bream.

Genetic variations have been detected among LCDVs isolated from different hosts $[10,24,25]$. These affected species belong to evolutionarily advanced orders of teleosts fishes, including these families: Cichlidae, Osphronemidae, Centrarchidae, Gobiidae, Chaetodontidae, Pomacentridae, Sciaenidae, Serranidae and Pleuronectidae. As far as the authors are aware, LCDV has not been previously reported in less-advanced fish orders, such as Siluriformes, Cyprinids and Salmonids.

The Iridoviridae family has been determined to have highly conserved regions within the MCP gene [11] making it an ideal target for the identification of the virus. On the basis of LCDV Tunisian sequences that have been published to date, low genomic variability was observed among isolates from different fish farms spaced over 7 years. The survey indicates that the newly identified LCDV isolates were clustered within genotype VII and shared $96-100 \%$ of sequence identity with other Tunisian LCDV isolates previously identified in 2005 [13] and in 2011 [10]. Sequences were also closely related to strains isolated from other regions of south Europe [13]. This could be due to the active trade of fish among farms located in the Mediterranean Sea (Spain, Italy, France and Turkey), which make it difficult to draw any conclusion about the geographical distribution of the isolates. Full genome sequencing would allow a more thorough determination of the phylogenetic relationship between local and imported LCDV strains and 
Table 2: List of isolates and accession numbers of sequences.

\begin{tabular}{|c|c|c|c|c|c|c|}
\hline Isolate & Host & Genotype & Year of isolation & Origin & Accession number & Reference \\
\hline LCDV-1 & Platichthysflesus & 1 & 1997 & Germany & L63545 & Schnitzler et al 1987 \\
\hline LCDVK1 Kor03 & Paralichthysolivaceus & II & 2003 & Korea & AY303804.1 & unpublished \\
\hline JF.Kor04 & Paralichthysolivaceus & II & 2004 & Korea & AY849391.1 & unpublished \\
\hline JF04Jeju.JP04 & Paralichthysolivaceus & II & 2005 & Japan & AB213003.1 & [10] \\
\hline JF00Yosu.Kor00 & Paralichthysolivaceus & II & 2000 & Korea & AB212999.1 & [10] \\
\hline JF03Yoshi.Jp03 & Paralichthysolivaceus & II & 2003 & Japan & AB212998.1 & [10] \\
\hline JF00Kuma & Paralichthysolivaceus & II & 2000 & Japan & AB212997.1 & [10] \\
\hline KRF.Kor04 & Sebastesschlegeli & III & 2004 & Korea & AY849392.1 & unpublished \\
\hline RF.Kor04 & Sebastesschlegeli & III & 2004 & Korea & AY823414.1 & Kim and Lee 2007 \\
\hline RF04Yosu.Kor04 & Sebastesschlegeli & III & 2004 & Korea & AB213005.1 & [10] \\
\hline RF04JinJu.Kor04 & Sebastesschlegeli & III & 2004 & Korea & AB213006.1 & [10] \\
\hline RF03Yosu.Kor03 & Sebastesschlegeli & III & 2003 & Korea & AB213004.1 & [10] \\
\hline LCDVRC CH06 & Rachycentroncanadum & IV & 2006 & China & EF103188.1 & [10] \\
\hline SB98Yosu & Sea bass & IV & 1998 & Korea & AB247938.1 & [10] \\
\hline RC1.CH06 & Rachycebtroncanadum & IV & 2006 & China & EF059992.1 & unpublished \\
\hline PGF05.Jp07 & Chanda baculis & V & 2007 & Korea & AB299163.1 & [6] \\
\hline PG06.Jp06 & Trichogasterleeri & VI & 2007 & Korea & AB299164.1 & [6] \\
\hline SA-Eilat.Isr06 & Sparus aurata & VII & 2006 & Israel & EF184306.1 & unpublished \\
\hline SA1.Tun11 & Sparus aurata & VII & 2011 & Tunisia & HE650105.1 & [23] \\
\hline SA2.Tun11 & Sparus aurata & VII & 2011 & Tunisia & HE650106.1 & [23] \\
\hline SA24.Fr09 & Sparus aurata & VII & 2009 & France & GU320739.1 & [14] \\
\hline SSE20 po08 & Solea senegalensis & VII & 2008 & Spain & GU320736.1 & [14] \\
\hline SA19 sp08 & Sparus aurata & VII & 2008 & Spain & GU320735.1 & [14] \\
\hline SA18 pro08 & Sparus aurata & VII & 2008 & Portugal & GU320734.1| & [14] \\
\hline SA16 & Sparus aurata & VII & 2008 & Iles De Canaris & GU320733.1 & [14] \\
\hline SA12Sp03 & Sparus aurata & VII & 2001 & Spain & GU320730.1 & [13] \\
\hline SSE11.Sp01 & Solea senegalensis & VII & 2001 & Spain & GU320729.1 & [14] \\
\hline SA9.Sp01 & Sparus aurata & VII & 2001 & Spain & GU320728.1 & Cano et al. 2007 \\
\hline SA8.Sp00 & Sparus aurata & VII & 2000 & Spain & GU320727.1 & [14] \\
\hline SA22.fr09 & Sparus aurata & VII & 2009 & France & GU320737.1 & [14] \\
\hline SA3sp97 & Sparus aurata & VII & 1997 & Spain & GU320724.1 & Garcia-Rosado et al. 1999 \\
\hline Leetown NFH.USA62 & Micropterus salmoides & VIII & 1962 & USA & GU290550.1 & Wolf 1962 \\
\hline YP1 & Percaflavescens & IX & 2011 & Canada & GU939626.2|YP1 & [13] \\
\hline DA1 Tun16 & Diplodusanularis & VII & 2014 & Tunisia & - & This study \\
\hline DV1 Tun16 & Diplodus vulgaris & VII & 2014 & Tunisia & - & This study \\
\hline Sarau1 Tun16 & Sardinella aurita & VII & 2014 & Tunisia & - & This study \\
\hline SS1 Tun16 & Sarpasalpa & VII & 2014 & Tunisia & - & This study \\
\hline
\end{tabular}

could elucidate more about the viral origin of the Tunisian isolates.

\section{Acknowledgement}

The present work was funded by the Tunisian ministry of Agriculture (IRESA, 03/0013). We generously thank Dr. Dolores
Castro for her precious help to initiate and revise this work by supplying the LCDV-positive control and unpublished PCR primers and protocols to our lab.

The authors declared no potential conflicts of interest with respect to the research, authorship, and/or publication of this article. 


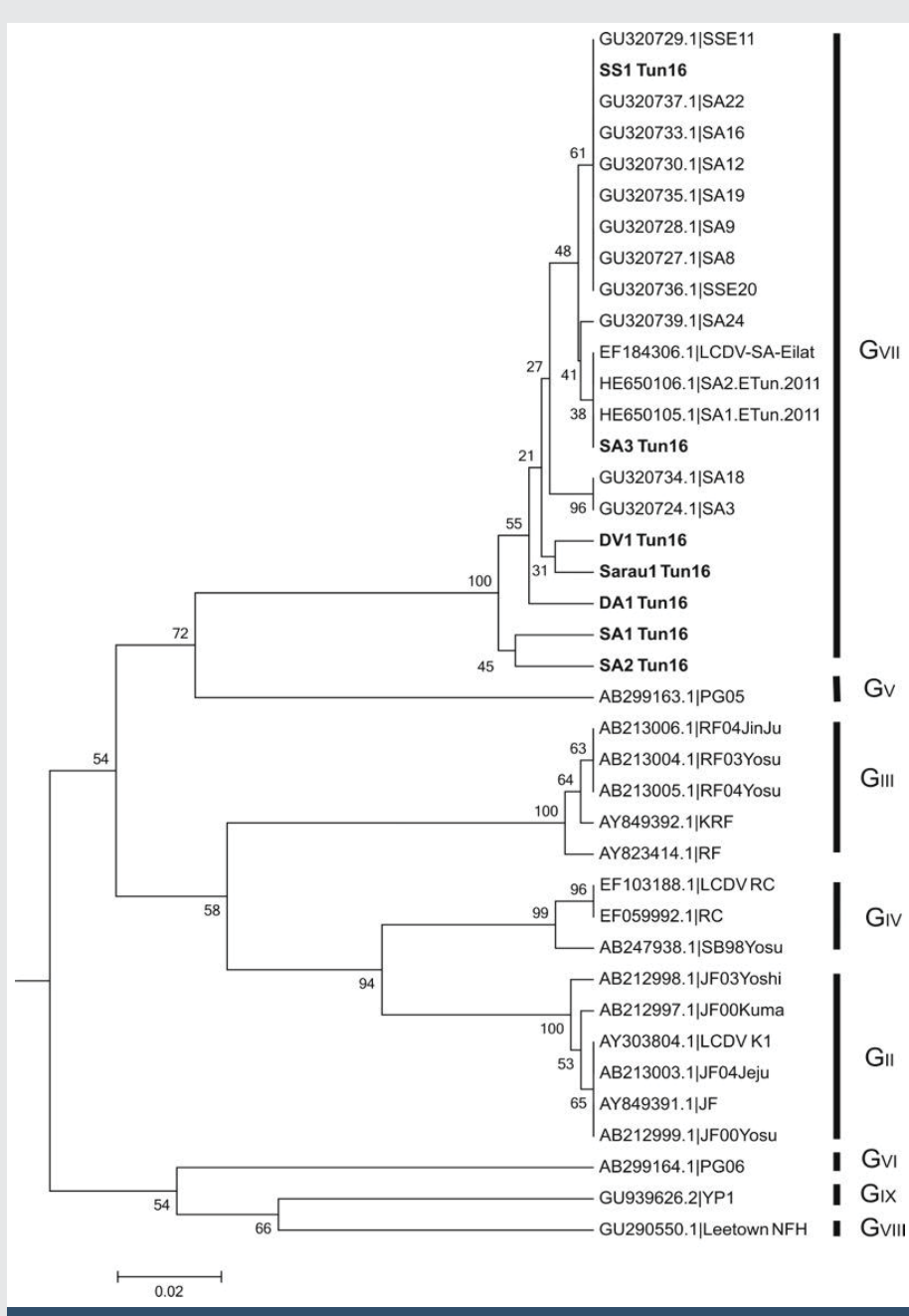

Figure 2: Phylogenetic relationships between 39 isolates of Lymphocystivirus based on a partial nucleotide sequence of the major capsid protein (MCP) gene. The evolutionary history was inferred using the UPGMA method (Sneath P.H.A. and Sokal R.R.,1973). The percentage of replicate trees in which the associated taxa clustered together in the bootstrap test (1000 replicates) are shown next to the branches (Felsenstein J.,1985). The evolutionary distances were computed using the Kimura 2-parameter method (Kimura M.,1980). and are in the units of the number of base substitutions per site. GenBank accession numbers and genotypes for nucleotide sequences and references are detailed in table II.

\section{References}

1. Anders K (1989) Lymphocystis disease of Fishes. viruses of lower vertebrates 141-160. Link: https://bit.ly/2Ty9HbK

2. Marcogliese DJ, Fournier M, Lacroix A, Cyr DG (2001) Non-specific immune response associated with infections of lymphocystis disease virus in American plaice, Hippoglossoidesplatessoides (Fabricius). J Fish Dis 24: 121 124. Link: https://bit.ly/2LZMqeg

3. Paperna I, Vilenkin M, de Matos AP (2001) Iridovirus infections in farmreared tropical ornamental fish. Dis Aquat Organ 48: 17-25. Link: https://bit.ly/2TBoBOE

4. Bunkley-Williams L, Williams EH, Phelps RP (2002) Does lymphocystis occur in pacora, Plagioscionsurinamensis (Sciaenidae), from Colombia? Acta Tropica 82: 7-9. Link: https://bit.ly/2ZxI06t

5. Sheng XZ, Zhan WB, Wang Y (2007) Whitespotter puffer Arothronhispidus, a new host for lymphocystis in Qingdao Aquarium of China. Diseases of Aquatic Organisms 75: 23-28. Link: https://bit.ly/2A2z3HI

6. Hossain M, Song JY, Kitamura SI, Jung SJ, Oh MJ (2008) Phylogenetic analysis of lymphocystis disease virusfrom tropical ornamental fish species based on a major capsidprotein gene. J Fish Dis 31: 473-479. Link: https://bit.ly/3c45QJI

7. Xu L, Feng J, Huang Y (2014) Identification of lymphocystis disease virus from paradise fish Macropodusopercularis (LCDVPF). Arch Virol 159: 2445-2449. Link: https://bit.ly/2LSgVmC

8. Huang X, Huang Y, Xu L, Wei S, Ouyang Z, Feng J (2015) Identification and characterization of a novel lymphocystis disease virus isolate from cultured grouper in China. J Fish Dis 38: 379-387. Link: https://bit.ly/36sI9tj

9. Smail DA, Munro ALS (2001) The virology of teleosts. In: Roberts RJ, editor Fish pathology. 3rd ed. Edinburgh: W.B. Saunders;p. 169-253.

10. Kitamura SI, Jung SJ, Kim WS, Nishizawa T, Yoshimizu M, OhM J (2006) A new genotype of Lymphocystisvirus, LCDV-RF, from lymphocystis diseased rockfish. Arch Virol 151: 607-615. Link: https://bit.ly/2XsC500

11. Tidona CA, Schnitzler $P$, Kehm R, Darai $G$ (1998) Is the major capsid protein of iridoviruses a suitable target for the study of viral evolution? Virus Genes 16 59- 66. Link: https://bit.ly/3ghoNff

12. Williams T, Barbosa-Solomieu V, Chinchar VG (2005) A decade of advances in iridovirus research. Virus Res 65: 173- 248. Link: https://bit.ly/36rpHS1

13. Palmer LJ, Hogan NS, Van den Heuvel MR (2012) Phylogenetic analysis and molecular methods for the detection of lymphocystis disease virus from yellow perch, Percaflavescens (Mitchell). J Fish Dis 35: 661-670. Link: https://bit.ly/2A2u4qD

14. Cano I, Valverde EJ, Lopez-Jimena B, Alonso MC, Garcia-Rosado E, et al. (2010) A new genotype of Lymphocystivirus isolated from cultured gilthead seabream, Sparus aurata L., and Senegalese sole, Solea senegalensis (Kaup). J Fish Dis 33: 695-700. Link: https://bit.ly/2yvumWx

15. Fisher W Bauchot ML, Schneider M (1987) Fiches F.A.O. Identification des espèces pour les besoins de la pêche "Révision 1" Méditerranée et Mer noire Zone de pêche 37. Volume I. Invertébrés marins. Rome, FAO 2: 761 - 1530.

16. Valverde EJ, Cano I, Labella A, Borrego JJ, Castro D (2016) Application of a new real-time polymerase chain reaction assay for surveillance studies of lymphocystis disease virus in farmed gilthead seabream. BMC Vet Res 12: 71. Link: https://bit.ly/3gl8aiU

17. Tamura K, Stecher G, Peterson D, Filipski A, Kumar S (2013) MEGA6: molecular evolutionary genetics analysis version 6.0. Mol Biol Evol 30: 2725-2729. Link: https://bit.ly/3d1WBei

18. Felsenstein J (1985) Confidence limits on phylogenies: An approach using the bootstrap. Evolution 39: 783-791. Link: https://bit.ly/2Xudqla

19. Borrego JJ, Castro D, Balebona MC, Garcia-Rosado E, Lopez-Cortes L (2001) Patologías que Afectan al Cultivo de la Dorada (Sparusaurata, L.) en la ComunidadAutón nomaAndaluza. Consejerı́a de Agricultura y Pesca, Junta de Andaluci'a, Sevilla.

20. Colorni A, Padros F (2011) Diseases and health management. Edited byPavlidis MA andMylonas CC.Sparidae: Biology and Aquaculture of Gilthead Sea Bream and other Species, Wiley-Blackwell, Oxford 321-357.

21. Dezfuli BS, Lui A, Giari L, CastaldelliMulero V, Noga EJ (2012) Infiltration and activation of acidophilic granulocytes in skin lesions of gilthead seabream, Sparus aurata, naturally infected with lymphocystis disease virus. Dev Comp Immunol 36: 174-182. Link: https://bit.ly/2LUAM4m

22. Abowei JFN, Briyai OF, Bassey SE (2011) A Review of Some Viral, Neoplastic Environmental and NutritionalDiseases of African FishBritish Journal of Pharmacology and Toxicology 2: 227-235.

23. Haddad-Boubaker S, Bouzgarou N, FakhfakhE, Khayech M, Ben Mohamed S, et al. (2013) Detection and GeneticCharacterization of Lymphocystis 
Disease Virus (LCDV) Isolated during Disease Outbreaks in Cultured Gilthead Sea Bream Sparus aurata in Tunisia. Fish Pathology 48: 101-104. Link: https://bit.ly/2ZxYPyj

24. Tidona CA, Darai G (1997) The complete DNA sequence of lymphocystis disease virus. Virology 230: 207-216. Link: https://bit.ly/3ehkrDb
25. Zhang QY, Feng X, Jian X, Li ZQ, Gui JF (2004) Complete Genome Sequence of Lymphocystis Disease Virus Isolated from China. J Virol 5: 6982-6994. Link: https://bit.ly/36wzgPI

\section{Discover a bigger Impact and Visibility of your article publication with}

\section{Peertechz Publications}

\section{Highlights}

* Signatory publisher of ORCID

* Signatory Publisher of DORA (San Francisco Declaration on Research Assessment)

* Articles archived in worlds' renowned service providers such as Portico, CNKI, AGRIS, TDNet, Base (Bielefeld University Library), CrossRef, Scilit, J-Gate etc.

* Journals indexed in ICMJE, SHERPA/ROMEO, Google Scholar etc.

* OAI-PMH (Open Archives Initiative Protocol for Metadata Harvesting)

* Dedicated Editorial Board for every journal

* Accurate and rapid peer-review process

* Increased citations of published articles through promotions

* Reduced timeline for article publication

Submit your articles and experience a new surge in publication services (https://www.peertechz.com/submission).

Peertechz journals wishes everlasting success in your every endeavours.

Copyright: @ 2020 Cherif N, et al. This is an open-access article distributed under the terms of the Creative Commons Attribution License, which permits unrestricted use, distribution, and reproduction in any medium, provided the original author and source are credited. 